\title{
Comparison of Analgesic Effects of Intraperitoneal Lornoxicam and Ropivacaine Administration in Laparoscopic Cholecystectomy
}

\author{
Laparoskopik Kolesistektomi Sonrası A ğr Tedavisinde Intraperitoneal Uygulanan \\ Lornoksikam ve Ropivakainin Etkisinin Karşılaştırılması \\ Ceyhun MEMEDOV, Öner MENTEŞ, Abdurrahman ŞiMŞEK, Can KEÇE, \\ Gökhan YAĞCI, Ali HARLAK, Ahmet COŞAR, ${ }^{1}$ Turgut TUFAN \\ Departments of General Surgery and ${ }^{1}$ Anesthesiology, Gülhane Military Medical School, Ankara
}

Submitted / Başvuru tarihi: 25.09.2008 Accepted/Kabul tarihi: 04.12.2008

\begin{abstract}
Objectives: In this randomized prospective study, we investigated the effects of lornoxicam vs. ropivacaine for the management of postoperative pain in patients undergoing elective laparoscopic cholecystectomy.
\end{abstract}

Patients and Methods: Patients were randomized into three groups and received $150 \mathrm{mg}(80 \mathrm{~mL})$ ropivacaine or $16 \mathrm{mg}$ lornoxicam $(80 \mathrm{~mL})$ or placebo ( $80 \mathrm{~mL}$ saline) via multi-regional intraperitoneal instillation and port sites infiltration. Patient-controlled analgesia (PCA) device was used. Tramadol $50 \mathrm{mg}$ tolerable dose, $5 \mathrm{mg} / \mathrm{hour}$ basal infusion, bolus dose $20 \mathrm{mg}$, locked $30 \mathrm{~min}, 4$ hour limit were applied as $200 \mathrm{mg}$. Postoperative pain was assessed with 100-mm visual analog scale (VAS) at rest, while coughing, and during mobilization. Pain scores were recorded in the post-anesthesia care unit, and at $2,4,8,12,18$ and $24 \mathrm{~h}$ after the surgery.

Results: At 24 h, VAS scores at rest and while coughing were found significantly lower in ropivacaine and lornoxicam group when compared with control group $(p=0.047)$. The percentage of patients needing tramadol was significantly lower with ropivacaine and lornoxicam compared with control $(p<0.001, p=0.018)$. There was no statistically significant difference between ropivacaine and lornoxicam group.

Conclusion: Multi-regional, intraperitoneal instillation and port site infiltration of ropivacaine and lornoxicam during laparoscopic cholecystectomy reduces the postoperative pain.

Key words: Laparoscopic cholecystectomy; ropivacaine; lornoxicam; postoperative pain.
Amaç: Prospektif randomize olarak yapılan bu çalışmada laparoskopik kolesistektomi sonrası ağrı tedavisinde lornoksikam ve ropivakainin etkisi araştırılmıştır.

Hastalar ve Yöntemler: Çalışmaya dahil edilen 45 hasta üç gruba randomize edildi. Hastalara $150 \mathrm{mg}(80 \mathrm{~mL})$ ropivakain, $16 \mathrm{mg}$ lornoksikam $(80 \mathrm{~mL})$ ve plasebo $(80$ $\mathrm{mL}$ saline) intraperitoneal olarak püskürtüldü ve port bölgelerine infiltre edildi. Ameliyat bitiminde hasta kontrollü analjezi cihazı ile tramadol $50 \mathrm{mg}$ yükleme dozu, $5 \mathrm{mg}$ bazal infüzyon, bolus doz $20 \mathrm{mg}$, kilitli kalma süresi $30 \mathrm{dk}$, 4 saatlik limit $200 \mathrm{mg}$ olarak planlandı. Hastaların ağrısı görsel analog skala (VAS) ile 0-100 olacak şekilde istirahat, öksürük sonrası ve mobilizasyon sırasında değerlendirildi. Ağrı skorları ilk saatte anestezi derlenme odasında ve 2., 4., 8., 12., 18., 24. saatlerde serviste değerlendirildi.

Bulgular: Ropivakain ve lornoksikam grubunda istirahat ve öksürük sonrası VAS değerleri kontrol grubuna göre daha düşük bulundu $(p=0.047)$. Tramadol tüketimi açısından, ropivakain ve lornoksikam grupları arasında fark bulunmazken ( $p>0.05$ ), kontrol grubuna göre bu iki grupta anlamlı düşük olarak bulundu $(p<0.001$, $p=0.018$ ). Ropivakain ve lornoksikam grubu arasında ise istatistiksel olarak anlamlı fark bulunmadı.

Sonuç: Ropivakain ve lornoksikamın port bölgelerine, intraperitoneal çoklu bölgeye laparoskopik kolesistektomi sonrası infiltrasyonu ameliyat sonrası ağrı tedavisinde etkin olarak bulunmuştur.

Anahtar sözcükler: Laparoskopik kolesistektomi; ropivakain; lornoksikam; ameliyat sonrası ağrı.

Correspondence (Illetişim adresi): Dr. Öner Menteş. Gülhane Askeri Tıp Akademisi Genel Cerrahi Anabilim Dalı, 06018 Ankara.

Tel: 0312 - 3045015 Fax (Faks): 0312 - 3045102 e-mail (e-posta): onermentes@yahoo.com

() Trakya Üniversitesi Tıp Fakültesi Dergisi. Ekin Tıbbi Yayıncııı tarafından basılımışır. Her hakkı sakııır.

(c) Medical Journal of Trakya University. Published by Ekin Medical Publishing. All rights reserved. 
Laparoscopic cholecystectomy (LC) has become a gold standard and preferred surgical technique for gall bladder pathologies because of an improved postoperative course compared with open surgery. ${ }^{[1,2]}$ Although LC results in less postoperative pain and/or reduced analgesic consumption, better cosmetic results, and a shorter hospital stay compared with open cholecystectomy, however, it is not a pain-free procedure. ${ }^{[2,3]}$ Early postoperative pain is the most prevalent and dominant complaint that requires strong analgesia including opiates after elective laparoscopic cholecystectomy. ${ }^{[4]}$ For that reason, many efforts have been made to improve postoperative analgesia after LC, but postoperative pain, however, does not completely disappear and several studies have shown that visceral pain is the major component. ${ }^{[5,6]}$ Nonetheless, post-cholecystectomy pain may be moderate or even severe for some patients during the first 24 postoperative hours, and has frequently been treated with nonsteroid anti-inflammatory drugs (NSAIDs) or opioid treatment. ${ }^{[7,8]}$

Local anesthetic infiltration is often used to improve pain relief after laparoscopic cholecystectomy. ${ }^{[5,9-13]}$ The postoperative analgesic effect of intraperitoneal administration of local anesthesia after laparoscopic gynecologic surgery has proved to be effective and safe but there is lack of consensus regarding the dose, concentration, site, and manner of administration. ${ }^{[14-18]}$ But the effect of the same procedure during laparoscopic cholecystectomy is controversial, and the reported results range from considerable pain reduction to no significant pain reduction. Therefore, we designed this prospective, randomized study to assess whether the intraperitoneal application of ropivacaine or lornoxicam yields any benefit in regard to postoperative pain and pulmonary function after laparoscopic cholecystectomy and compare these effects.

\section{PATIENTS AND METHODS}

The study protocol was approved by our hospital ethical committee, and informed consent was obtained from each patient. Forty-five patients with ASA physical status I-II scheduled to undergo laparoscopic cholecystectomy were included in this prospective and randomized study from January 2006 to June 2006 in General Surgery Clinic. The patients underwent elective laparoscopic cholecystectomy under general anesthesia and a multiregional blockade with ropivacaine, lornoxicam or saline (placebo).

The criteria for exclusion were ASA physical status III or greater, and patients having papillotomy by endoscopic retrograde cholangiopancreatography within one month before operation, patients allergic to local anesthetics and those with a history of cardiac disease. Patients were also excluded if they had operation for acute cholecystitis or if the operation was converted to an open procedure. Also, to study the real analgesic effects of local anesthetics, patients were excluded when they had postoperative complications, which could increase postoperative pain. Thus, only those who were likely to have a simple laparoscopic cholecystectomy were included. Before the end of the surgery, metoclopramide (10 mg) was given intravenously to all patients to reduce the incidence of nausea and vomiting. No patient underwent the placement of intraperitoneal drain. Patients were divided into three randomized groups with 15 patients in each group.

In the control group, at the end of the surgical process, $80 \mathrm{~mL}$ of saline was instillated under direct vision by the surgeon into the gallbladder bed after partial retrograde release of the gallbladder, right and left subdiaphragmatic area and instillation to the visceral peritoneum at the end of the procedure. The remaining 20 $\mathrm{ml}$ salin was injected into the four port access in which one port was injected $5 \mathrm{ml}$ 's. For the patients in the $2 \mathrm{nd}$ (ropivacaine) group, at the end of the surgical process, 80 $\mathrm{ml}$ ropivacaine (Naropin ${ }^{\circledR} 7.5 \mathrm{mg} / \mathrm{ml} 20 \mathrm{ml}$ was diluted with $80 \mathrm{ml}$ saline totally $100 \mathrm{ml}$ solution) was instillated into the gallbladder bed, right and left subdiaphragmatic area and the visceral peritoneal surface respectively, then the remaining $20 \mathrm{ml}$ was infiltrated around the port trocar sites in $5 \mathrm{ml}^{\prime} \mathrm{s}$.

In the 3rd group, at the end of the surgical process, $80 \mathrm{ml}$ lornoxicam (Xefo® flk $16 \mathrm{mg}$ was diluted with 100 $\mathrm{ml}$ saline totally $100 \mathrm{ml}$ solution) was instillated into the gallbladder bed, right and left subdiaphragmatic area and the viseral periton surface respectively, then the remaining $20 \mathrm{ml}$ was infiltrated around the port trocar sites in $5 \mathrm{ml}^{\prime} \mathrm{s}$.

All patients received the same anesthetic technique. The beginning of surgery for prophylaxis $0.5 \mathrm{mg}$ atropin IM was injected to the patients and following the general anesthesia and intubation, after injecting giving fentanyl+lidocain as an induction for the anesthesia, in the following period $\% 66 \mathrm{NO}_{2}+\% 33 \mathrm{O}_{2}+\% 1-1.5$ isoflurane (Forane $\left.{ }^{\circledR}\right)+$ Vecuronium bromide (Norcuron ${ }^{\circledR}$ ) $2 \mathrm{mg} / \mathrm{kg} /$ hour IV; and in waking up period $\% 100 \mathrm{O}_{2}$ + decurarisation were applied. Mean arterial pressure, $\mathrm{HR}$ and $\mathrm{SpO}_{2}$ were recorded before and after induction, after intubation and every 5 min intervals until the end of the operation. The same three surgeons performed all operations. Before surgery, for measuring pain and nausea, the patients were educated to use a $100-\mathrm{mm}$ visual analog scale (VAS).

Laparoscopic cholecystectomy was performed by the standard "American" technique. ${ }^{[19]}$ Intraoperative cholangiography was not performed. All patients were given cefamezin $1 \mathrm{~g}$ at the beginning of surgery. With infraumblical incision, pneumoperitoneum formation was supplied with the carbon dioxide $\left(\mathrm{CO}_{2}\right)$ insuflation inside the abdomen from the Veres injector. During laparoscopy, intraabdominal pressure was maintained at $10-12 \mathrm{~mm} \mathrm{Hg}$. After the gallbladder was removed, 
Table 1. Demographic variables and the duration of surgery

\begin{tabular}{lcccc}
\hline & $\begin{array}{c}\text { Group I } \\
(\mathrm{n}=15)\end{array}$ & $\begin{array}{c}\text { Group II } \\
(\mathrm{n}=15)\end{array}$ & $\begin{array}{c}\text { Group III } \\
(\mathrm{n}=15)\end{array}$ & $p$ \\
\hline Gender (male/female) & $4 / 11$ & $5 / 10$ & $2 / 13$ & 0.93 \\
Age (years) & 55 & 46.5 & 47.5 & 0.86 \\
& $(26-84)$ & $(24-69)$ & $(27-68)$ & \\
Body weight (kg) & 72 & 75 & 78 & 0.72 \\
& $(55-100)$ & $(60-98)$ & $(58-95)$ & \\
Height (cm) & $165.4 \pm 10.2$ & $163.8 \pm 9.7$ & $168.0 \pm 9.4$ & 0.77 \\
& $(155-177)$ & $(154-175)$ & $(151-177)$ & \\
ASA (I/II) & $13 / 2$ & $10 / 5$ & $12 / 3$ & 0.30 \\
Duration of surgery (min) & 84 & 74.9 & 70 & 0.44 \\
& $(60-200)$ & $(30-120)$ & $(50-105)$ & \\
\hline
\end{tabular}

the apparatus of the Air Pomp (Northgate Technologies Incorporated Chicago, IL, USA) device was placed into the abdomen from the subcostal trocar and the medicine was sprayed intraperitoneal aerosolization technique developed previously by Alkhamesi. ${ }^{[20]}$ The $\mathrm{CO}_{2}$ was carefully evacuated at the end of surgery by manual compression of the abdomen with open trocars.

In the postoperative period, Abbott "Pain Management Provider" patient-controlled analgesia (PCA) device was used for all the patients and Tramadol $50 \mathrm{mg}$ tolerable dose, $5 \mathrm{mg} /$ hour basal infusion, bolus dose $20 \mathrm{mg}$, locked $30 \mathrm{~min}, 4$ hour limit were applied as

Table 2. Hourly and general VAS averages according to the groups

\begin{tabular}{lcccc}
\hline Hours & Group I & Group II & Group III & General \\
\hline 0 & 80 & 60 & 50 & 67.5 \\
& $(50-100)$ & $(10-90)$ & $(30-100)$ & $(10-100)$ \\
2 & 65 & 40 & 50 & 48.7 \\
4 & $(30-90)$ & $(0-80)$ & $(10-80)$ & $(0-90)$ \\
& 50 & 20 & 20 & 30 \\
8 & $(30-80)$ & $(0-60)$ & $(0-50)$ & $(0-80)$ \\
& 40 & 10 & 10 & 20 \\
12 & $(20-60)$ & $(0-50)$ & $(0-40)$ & $(0-60)$ \\
& 30 & 10 & 10 & 20 \\
18 & $(10-100)$ & $(0-35)$ & $(0-30)$ & $(0-100)$ \\
& 20 & 5 & 0 & 10 \\
24 & $(10-50)$ & $(0-20)$ & $(0-30)$ & $(0-70)$ \\
& 10 & 0 & 0 & 5 \\
Mean & $(10-25)$ & $(0-30)$ & $(0-30)$ & $(0-50)$ \\
$(24$ hours $)$ & $(24.2-58.2)$ & $(8.5-38.5)$ & $(10.0-37.1)$ & $(7.1-59.2)$ \\
\hline Groups & $p$ & & & \\
\hline $1-2$ & $0,0001^{*}$ & & & \\
$1-3$ & $0,0001^{*}$ & & & \\
$2-3$ & 0.603 & & & \\
\hline
\end{tabular}

${ }^{*} \mathrm{p}<0.05$ is statistically significant.
$200 \mathrm{mg}$ form. The patients were asked about the location of pain, whether at the shoulder, incision sites, and/ or inside the abdomen. The intensity of the different postoperative pain components were recorded on a 100$\mathrm{mm}$ visual analog scale at rest (supine, $10^{\circ}-15^{\circ}$ head up), on coughing, and during mobilization (patients were asked to move from the supine to the sitting position). Patients were told to indicate the degree of their pain by VAS, when they were asked to evaluate the intensity of their pain. Standard patient monitoring was used. Pain scores, morphine consumption, nausea, and vomiting, sedation status, breathing rate $/ \mathrm{min}, \mathrm{SpO}_{2}$, systolic and

Table 3. The averages of VAS scores after hourly coughs according to the groups

\begin{tabular}{|c|c|c|c|c|}
\hline Hours & Group I & Group II & Group III & General \\
\hline \multirow[t]{2}{*}{0} & 90 & 70 & 60 & 77.5 \\
\hline & $(60-100)$ & $(30-90)$ & $(30-100)$ & $(30-100)$ \\
\hline \multirow[t]{2}{*}{2} & 77 & 50 & 60 & 59.4 \\
\hline & $(30-90)$ & $(0-80)$ & $(10-80)$ & $(0-90)$ \\
\hline \multirow[t]{2}{*}{4} & 60 & 20 & 30 & 40 \\
\hline & $(40-100)$ & $(0-80)$ & $(0-80)$ & $(0-100)$ \\
\hline \multirow[t]{2}{*}{8} & 60 & 10 & 20 & 27.5 \\
\hline & $(25-100)$ & $(0-40)$ & $(0-70)$ & $(0-100)$ \\
\hline \multirow[t]{2}{*}{12} & 42.5 & 10 & 10 & 25.6 \\
\hline & $(15-80)$ & $(0-40)$ & $(0-50)$ & $(0-80)$ \\
\hline \multirow[t]{2}{*}{18} & 30 & 10 & 10 & 20 \\
\hline & $(15-60)$ & $(0-40)$ & $(0-60)$ & $(0-80)$ \\
\hline \multirow[t]{2}{*}{24} & 20 & 10 & 10 & 15 \\
\hline & $(10-60)$ & $(0-40)$ & $(0-50)$ & $(0-60)$ \\
\hline Mean & 56.7 & 25.7 & 32.8 & 39.8 \\
\hline (24 hours) & $(38.5-78.5)$ & $(14.2-50.0)$ & $(11.4-69.2)$ & $(11.4-78.5)$ \\
\hline Groups & $p$ & & & \\
\hline $1-2$ & $0,0001^{*}$ & & & \\
\hline $1-3$ & $0,0001^{*}$ & & & \\
\hline $2-3$ & 0.718 & & & \\
\hline
\end{tabular}




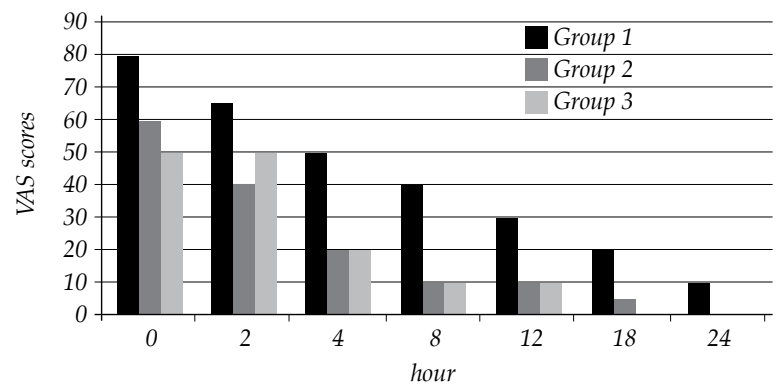

Fig. 1. General and hourly VAS scores according to groups.

diastolic blood pressures, pulse (rate/ $\mathrm{min}$ ) were recorded immediately at the arrival in the post-anesthesia care unit (PACU), and at 2, 4, 8, 12, 18 and $24 \mathrm{~h}$ after the surgery. If patients experienced nausea or vomiting, metoclopramide $(0.5 \mathrm{mg} / \mathrm{kg} \mathrm{IV})$ was given.

At the 12th and 24th hours, the satisfaction of the patients were examined. At the 12th and 24th hours, the peristaltism and flatulence of the patients were recorded. After 12 hours from the surgery, the patients were mobilized. Daily analgesic consumption was also recorded. Patients in whom laparotomy was required during surgery and those with inadequate analgesia necessitating rescue analgesics were excluded from the study.

\section{Statistical Analysis}

An a priori power analysis was performed as a component of design to estimate required total sample size as a function of power $1-\beta=0.80$, with the medium effect size 0.55 , and $\alpha=0.05$. The power calculation was computed using $G$ power version 2 (Franz Faul \& Edgar Erdfelder). Consequently, the adequate inclusion number was determined to be 15 patients in each study group (a total of 45 patients). We included 45 patients in the study. The results were given in terms of percentages and the mediums (lowest-highest). For the continuous variables in the evaluation of the differences between the groups Mann-Whitney U-test, for the discontinuous variables, Fisher's definitive test were used. For statistical significance, it was accepted as $\mathrm{p}<0.05$. The statistical analysis was performed by the SPSS 10.0 statistical software package (SPSS Inc., Chicago, Illinois, USA).

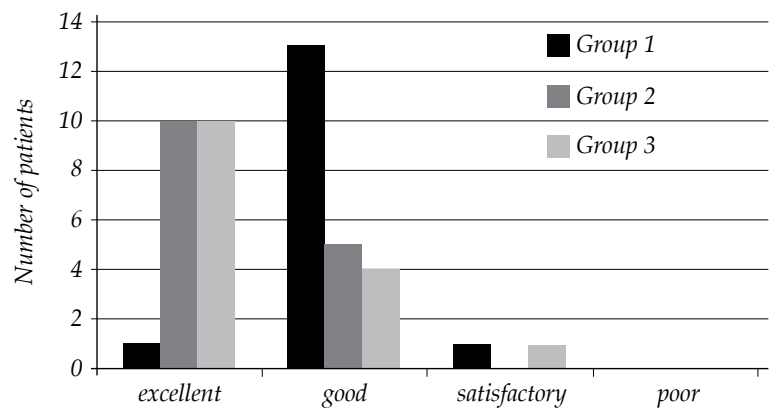

Fig. 3. General patient satisfaction average at the 12th hour.

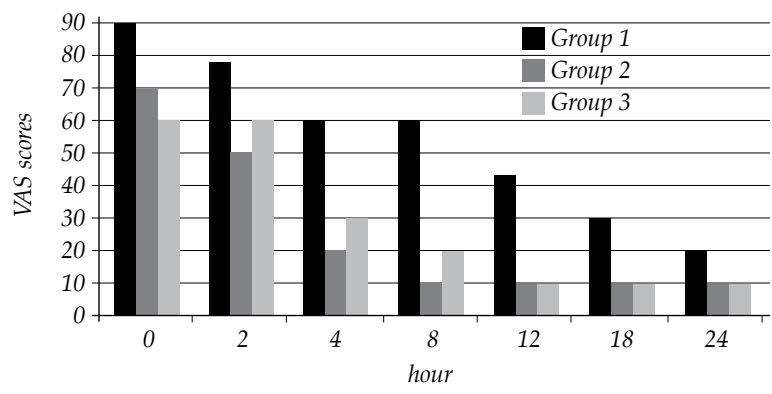

Fig. 2. Averages of VAS after hourly coughs according to groups.

\section{RESULTS}

A total of 45 patients had participated in the study with 15 patients in each group. Because three patients did not want to participate, the operations of four patients were started laparoscopically and after that, converted to open cholecystectomy, so they were left out of the study. Instead of these patients, other seven patients were included in the study. There were no significant differences between the groups with regard to demographic variables (age, gender, weight and height) and ASA physical status or the mean duration of surgery in minutes (Table 1). Hourly and general VAS averages according to the groups are shown in Table 2 and Fig. 1. According to the VAS averages, statistical significance between 1 st and 2 nd groups ( $\mathrm{p}=0.0001)$, statistical significance between 1st and 3rd groups ( $p=0.0001)$, statistical non-significance between 2 nd and 3rd groups $(p=0.603)$ were found. The averages of VAS after hourly coughs according to the groups are shown in Table 3 and Fig. 2. According to the VAS averages after coughing, statistical significance between 1st and 2nd groups $(\mathrm{p}=0.0001)$, statistical significance between 1st and 3rd groups $(\mathrm{p}=0.0001)$, and statistical non-significance between $2 \mathrm{nd}$ and 3rd groups were found $(p=0.718)$. The general patient satisfaction averages at 12th and 24th hours are shown in Figs. 3 and 4. According to the patient satisfaction averages, statistical significance between 1st and 2nd groups $(\mathrm{p}=0.0001)$, statistical significance between 1st and 3rd groups ( $\mathrm{p}=0.0001)$, and statistical non-significance between 2 nd and 3rd groups were found ( $p=0.12$ ). The hourly and general sedation averages according to the groups are shown in Fig. 5. With regard to the seda-

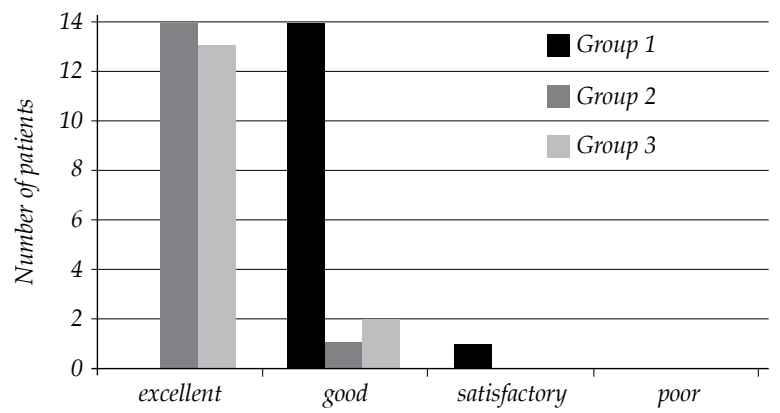

Fig. 4. General patient satisfaction average at the 24th hour. 


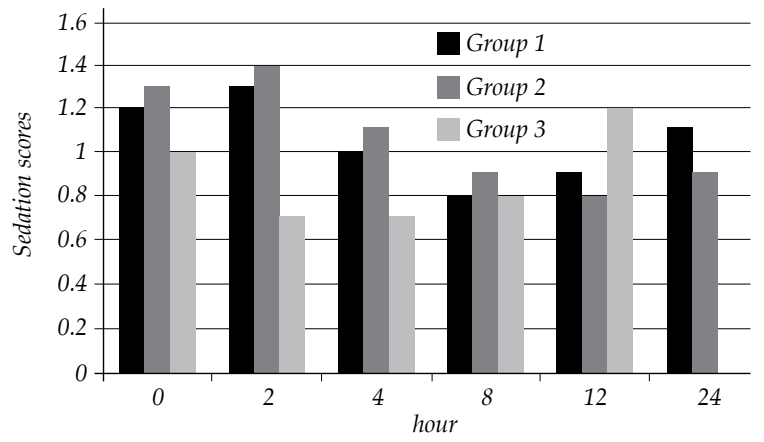

Fig. 5. Patient sedation scores.

tion averages, statistical insignificance between 1st and 2nd groups $(\mathrm{p}=0.57)$, statistical insignificance between 1 st and 3rd groups $(p=0.12)$, and statistical insignificance between 2 nd and 3 rd groups were found $(p=0.15)$. Total tramadole consumption of the patients at the end of 24th hour and the PCA button pressing numbers are shown in Fig. 6. At the end of the 24th hour after the surgery, with regard to the total tramadole consumption and PCA button pressing numbers, statistical significance between 1st and 2nd groups $(\mathrm{p}=0.0001, \mathrm{p}=0.0001)$, statistical significance between 1 st and 3rd groups $(p=0.0001$, $\mathrm{p}=0.0001$ ), and statistical insignificance between $2 \mathrm{nd}$ and 3rd groups were found $(\mathrm{p}=0.52, \mathrm{p}=0.21)$.

With regard to the $\mathrm{SpO}_{2}$ averages, statistical insignificance between 1st and 2nd groups $(\mathrm{p}=0.86)$, statistical insignificance between 1 st and $3 r d$ groups $(p=0.44)$, and statistical insignificance between 2 nd and 3 rd groups were found $(\mathrm{p}=0.87)$.

With regard to the hourly peristaltisms of the patients according to the treatment protocols, no significant difference was found between the treatment groups $(\mathrm{p}=0.39)$.

With regard to the hourly flatulence of the patients according to the treatment protocols, no significant difference was found between the groups $(p=0.22)$. With regard to the side effects according to the treatment protocols, statistical significance between 1st and 2nd groups $(\mathrm{p}=0.0001)$, statistical significance between 1st and 3rd groups $(\mathrm{p}=0.03)$, and statistical insignificance between 2 nd and 3rd groups were found $(p=0.81)$.

Shoulder pain was reported by eight patients (control group $=5$, ropivacaine group $=1$, lornoxicam group $=2$ ) but this result was not statistically significant ( $p>0.005)$.

\section{DISCUSSION}

Minimal invasive surgery holds an important position in today's practice for many diseases in general and gynecologic surgery. Laparoscopic cholecystectomy (LC) results in less postoperative pain and/or reduced analgesic consumption as well as morphine as compared with open cholecystectomy. So it is thus logical to sug-

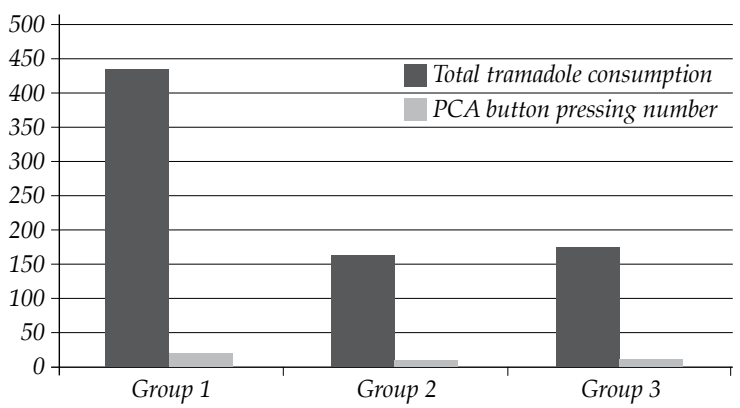

Fig. 6. Total tramadole consumption and PCA button pressing numbers according to groups.

gest that returning to normal daily activities is also more rapid with laparoscopy. ${ }^{[21-24]}$ Postoperative pain, however, does not completely disappear after laparoscopic cholecystectomy and, in the early postoperative period, serious pain and nausea may occur and a strong analgesia may be necessary. ${ }^{[25-28]}$

The exact etiology of pain after laparoscopic cholecystectomy is still unclear, however, it appears to be multifactorial and the causes include, abdominal wall trauma by trochar entrances, diaphragmatic irritation secondary to $\mathrm{CO}_{2}$ insufflation and pneumoperitoneum, type and temperature of insufflated gas and intraabdominal $\mathrm{pH}$, residual intraperitoneal gas, intraabdominal trauma secondary to gallbladder removal, microruptures of the parietal peritoneum due to abdominal distension, chemical irritation of the peritoneum, etc. ${ }^{[23,29-31]}$ Therefore, multimodal analgesic techniques are necessary. For the decrement of postoperative pain after the laparoscopy, some methods such as rectus cover block, ${ }^{[32]}$ intraabdominal drain placement in order to throw out $\mathrm{CO}_{2}$ pneumoperitoneum, ${ }^{[33]}$ intraabdominal instillation of local anesthetics, ${ }^{[33]}$ intraperitoneal infiltration of the local anesthetics or opioids, ${ }^{[24,34,35]}$ the use of intramuscular morphine injections, patient-controlled analgesia, and injection of local anesthetics into the port sites are suggested. ${ }^{[36]}$

Because intraperitoneal injection of the local anesthetics during gynecologic surgery has proved to be effective and safe, it was thus logical to suggest that this technique may also provide an effective block of postoperative visceral pain after laparoscopic cholecystectomy. ${ }^{[18,37]}$ The clinical significance of this pain reduction is questionable. In the studies, after the laparoscopic surgeries, the intraperitoneal local anesthetics are found to be very effective for the decrement of the postoperative pain. ${ }^{[38,39]}$ This non-invasive method has a minimum risk and it can be easily applied. Besides, there are studies showing that the application of intraperitoneal anesthetic administration is not useful for the prevention of postoperative pain. ${ }^{[40]}$ Because laparoscopic surgery, a minimally invasive technique, is associated with reduced surgical trauma, the use of local anesthetic infiltration for effica- 
cious postoperative analgesia should allow widespread use of laparoscopic day-case surgery. Non-steroidal anti-inflammatory drugs (NSAIDs) provide effective analgesia in patients with acute postoperative pain after laparoscopic cholecystectomy, either as a substitute for or as an adjunct to opioid analgesia.

COX-2 inhibitors are newer drugs having less adverse effects. Lornoxicam $\left(\right.$ Xefo $^{\circledR}$ ) which is a potent short acting new NSAID of the oxicam class, has been used worldwide. ${ }^{[41,42]}$ The short plasma half-life (three to five hours) of it may provide advantages over other NSAIDs. ${ }^{[2,43]}$ When inhibiting the cyclooxygenases enzyme as a non-selective form, ${ }^{[43]}$ in the gynecologic and orthopedics cases, for the pain relief after the surgery period, it is reported that it is as efficacious as morphine, ${ }^{[44]}$ meperidin, ${ }^{[45]}$ and tramadole. ${ }^{[46]}$ Lornoxicam has been successfully used in prevention and treatment of postoperative pain in patients undergoing gynecological operations. Studies showed that lornoxicam administered preemptively improved the quality of postoperative analgesia and opioid consumption. ${ }^{[4]}$

Ropivacaine (1-propyl-2', 6'-pipecoloxylidide hydrochloride) a new long-acting amide local anesthetic that is formulated as the pure S-enantiomer, is chemically related to bupivacaine, but it has been shown to be less toxic to cardiac and central nervous system. ${ }^{[48-50]}$ This drug possesses anti-inflammatory activity that may further reduce pain when administered locally. ${ }^{[51,52]}$ The reason of preferring ropivacain in our study is that it is a long-acting agent (6-12 hours), has less motor blockages and a less cardiotoxicity than bupivacain. ${ }^{[25]} \mathrm{We}$ have provided nearly total blocks by giving the local anesthetics agents to all regions that many surgical manipulation were applied, such as hepatoduodenal ligaman, gallbladder bed, subdiaphragmatic and subhepatic area. Through this application, we have decreased the pain of the patients in a satisfactory form. The fact that the general and after coughing VAS scores were statistically significant between the 1st and 2nd groups shows us that ropivacain is more effective than placebo significantly. As a result, somato-visceral local anesthetic block combined with $150 \mathrm{mg}$ ropivacain decreases the opioid consumption and nausea in the first 24 hours of the postoperative pain treatment.

We have applied lornoxicam at the end of the surgical process to the same anatomical areas with the same volume. When the placebo and the lornoxicam groups are compared, it is stated that lornoxicam is more effective on the postoperative pain. Although lornoxicam is not a local anesthetic agent, since a COX inhibitor decreases the secretion of the pain mediators in the areas where surgical manipulation is applied and besides its analgesic effect, it also shows a local antinociceptive effect.

In this study, multiregional intraperitoneal instillation and injection of lornoxicam and ropivacaine by the purpose of preventing the pain after laparoscopic cholecystectomy was performed and an effective postoperative analgesia was determined.

Shoulder pain is a common outcome and frequent complication after LC and can delay return to normal activities. It has been reported in $35 \%-63 \%$ of cases. ${ }^{[53]}$ It occurs after diaphragmatic stretching with phrenic nerve neuropraxia and reported after laparoscopic cholecystectomy is markedly lower than that reported after gynecologic laparoscopy. ${ }^{[53-55]}$ We found a low incidence of shoulder pain in all treatment groups, because the residual intraperitoneal $\mathrm{CO}_{2}$ was carefully removed by the surgeon.

Although we did not encounter nausea and vomiting between the patients in the 2 nd and 3rd treatment groups in the first postoperative 24 hours, nausea occurred in seven patients in SF group in the postoperative period. This finding is statistically significant and we think that this is related with the further consumption of opioid in SF group.

In conclusion, this study showed that the multiregional intraperitoneal instillation and port sites infiltration of ropivacaine and lornoxicam during laparoscopic cholecystectomy is a noninvasive, rapid, safe and simple analgesic technique that reduces the pain and the total morphine consumption without adverse effects.

In summary, both lornoxicam and ropivacaine were effective at preventing pain over the first $24 \mathrm{~h}$ after laparoscopic cholecystectomy when intraperitoneally instilled and injected at the port sites at the end of cholecystectomy.

\section{REFERENCES}

1. Joris J, Cigarini I, Legrand M, Jacquet N, De Groote D, Franchimont $\mathrm{P}$, et al. Metabolic and respiratory changes after cholecystectomy performed via laparotomy or laparoscopy. Br J Anaesth 1992;69:341-5.

2. Downs SH, Black NA, Devlin HB, Royston CMS, Russell RCG. A systematic review of the effectiveness and safety of laparoscopic cholecystectomy. Ann R Coll Surg 1996;78:241-323.

3. Putensen-Himmer G, Putensen C, Lammer H, Lingnau W, Aigner F, Benzer H. Comparison of postoperative respiratory function after laparoscopy or open laparotomy for cholecystectomy. Anesthesiology 1992;77:675-80.

4. Ure BM, Troidl H, Spangenberger W, Dietrich A, Lefering R, Neugebauer E. Pain after laparoscopic cholecystectomy. Intensity and localization of pain and analysis of predictors in preoperative symptoms and intraoperative events. Surg Endosc 1994;8:90-6.

5. Joris J, Thiry E, Paris P, Weerts J, Lamy M. Pain after laparoscopic cholecystectomy: characteristics and effect of intraperitoneal bupivacaine. Anesth Analg 1995;81:379-84.

6. Møiniche S, Jørgensen H, Wetterslev J, Dahl JB. Local anesthetic infiltration for postoperative pain relief after laparoscopy: a qualitative and quantitative systematic review of intraperitoneal, port-site infiltration and mesosalpinx block. Anesth Analg 2000;90:899-912. 
7. Saunders CJ, Leary BF, Wolfe BM. Is outpatient laparoscopic cholecystectomy wise? Surg Endosc 1995;9:1263-8.

8. Berggren U, Gordh T, Grama D, Haglund U, Rastad J, Arvidsson D. Laparoscopic versus open cholecystectomy: hospitalization, sick leave, analgesia and trauma responses. Br J Surg 1994;81:1362-5.

9. Mraović B, Jurisić T, Kogler-Majeric V, Sustic A Intraperitoneal bupivacaine for analgesia after laparoscopic cholecystectomy. Acta Anaesthesiol Scand 1997;41:193-6.

10. Pasqualucci A, de Angelis V, Contardo R, Colò F, Terrosu G, Donini A, et al. Preemptive analgesia: intraperitoneal local anesthetic in laparoscopic cholecystectomy. A randomized, double-blind, placebo-controlled study. Anesthesiology 1996;85:11-20.

11. Chundrigar $T$, Hedges AR, Morris R, Stamatakis JD. Intraperitoneal bupivacaine for effective pain relief after laparoscopic cholecystectomy. Ann R Coll Surg Engl 1993;75:437-9.

12. Scheinin B, Kellokumpu I, Lindgren L, Haglund C, Rosenberg PH. Effect of intraperitoneal bupivacaine on pain after laparoscopic cholecystectomy. Acta Anaesthesiol Scand 1995;39:195-8.

13. Szem JW, Hydo L, Barie PS. A double-blinded evaluation of intraperitoneal bupivacaine vs saline for the reduction of postoperative pain and nausea after laparoscopic cholecystectomy. Surg Endosc 1996;10:44-8.

14. Helvacioglu A, Weis R. Operative laparoscopy and postoperative pain relief. Fertil Steril 1992;57:548-52.

15. Narchi P, Benhamou D, Fernandez H. Intraperitoneal local anaesthetic for shoulder pain after day-case laparoscopy. Lancet 1991;338:1569-70.

16. Callesen T, Hjort D, Mogensen T, Schouenborg L, Nielsen D, Reventlid H, et al. Combined field block and i.p. instillation of ropivacaine for pain management after laparoscopic sterilization. Br J Anaesth 1999;82:586-90.

17. Narchi P, Benhamou D, Bouaziz H, Fernandez H, Mazoit JX. Serum concentrations of local anaesthetics following intraperitoneal administration during laparoscopy. Eur J Clin Pharmacol 1992;42:223-5.

18. Benhamou D, Narchi P, Mazoit JX, Fernandez H. Postoperative pain after local anesthetics for laparoscopic sterilization. Obstet Gynecol 1994;84:877-80.

19. Litwin DE, Girotti MJ, Poulin EC, Mamazza J, Nagy AG. Laparoscopic cholecystectomy: trans-Canada experience with 2201 cases. Can J Surg 1992;35:291-6.

20. Alkhamesi NA, Ridgway PF, Ramwell A, McCullough PW, Peck DH, Darzi AW. Peritoneal nebulizer: a novel technique for delivering intraperitoneal therapeutics in laparoscopic surgery to prevent locoregional recurrence. Surg Endosc 2005;19:1142-6.

21. McGinn FP, Miles AJ, Uglow M, Ozmen M, Terzi C, Humby M. Randomized trial of laparoscopic cholecystectomy and mini-cholecystectomy. Br J Surg 1995;82:1374-7.

22. Zubaroğlu E, Çalışkan K, Keskin A, Serim Ç, Seratlı $\mathrm{O}$, Özgüven R. Laparoskopik ve açı kolesistektominin postoperatif ağrı yönünden karşılaştııılması. Ağrı Dergisi 1997;9:24-9.

23. Møiniche S, Mikkelsen S, Wetterslev J, Dahl JB. A qualitative systematic review of incisional local anaesthesia for postoperative pain relief after abdominal operations. Br J Anaesth 1998;81:377-83.

24. Wills VL, Hunt DR. Pain after laparoscopic cholecystectomy. Br J Surg 2000;87:273-84.

25. Kehlet H, Gray AW, Bonnet F, Camu F, Fischer HB, McCloy RF, et al. A procedure-specific systematic review and consensus recommendations for postoperative analgesia following laparoscopic cholecystectomy. Surg Endosc 2005;19:1396-415.

26. Alexander JI. Pain after laparoscopy. Br J Anaesth 1997;79:369-78.

27. Bisgaard T, Klarskov B, Trap R, Kehlet H, Rosenberg J. Pain after microlaparoscopic cholecystectomy. A randomized double-blind controlled study. Surg Endosc 2000;14:340-4.

28. Callesen T, Hjort D, Mogensen T, Schouenborg L, Nielsen D, Reventlid H, et al. Combined field block and i.p. instillation of ropivacaine for pain management after laparoscopic sterilization. Br J Anaesth 1999;82:586-90.

29. Elhakim M, Elkott M, Ali NM, Tahoun HM. Intraperitoneal lidocaine for postoperative pain after laparoscopy. Acta Anaesthesiol Scand 2000;44:280-4.

30. Lee IO, Kim SH, Kong MH, Lee MK, Kim NS, Choi YS, et al. Pain after laparoscopic cholecystectomy: the effect and timing of incisional and intraperitoneal bupivacaine. Can J Anaesth 2001;48:545-50.

31. Labaille T, Mazoit JX, Paqueron X, Franco D, Benhamou D. The clinical efficacy and pharmacokinetics of intraperitoneal ropivacaine for laparoscopic cholecystectomy. Anesth Analg 2002;94:100-5.

32. Kehlet H. Effect of postoperative pain treatment on outcome-current status and future strategies. Langenbecks Arch Surg 2004;389:244-9.

33. Abdel-Raouf $\mathrm{M}$, Amer H. Postoperative analgesic effects of intraperitoneal NMDA receptor antagonists (ketamine and magnesium) in patients undergoing laparoscopic cholecystectomy. Egypt J Anaesth 2004:20;107-11.

34. Raetzell M, Maier C, Schröder D, Wulf H. Intraperitoneal application of bupivacaine during laparoscopic cholecystectomy--risk or benefit? Anesth Analg 1995;81:967-72.

35. Razek EA. Intraperitoneal levobupivacaine for analgesia after laparoscopic cholecystectomy. Egypt J Anaesth 2003;19:249-54.

36. Ghezzi F, Cromi A, Bergamini V, Raffaelli R, Crotti S, Segredini $R$, et al. Preemptive port site local anesthesia in gynecologic laparoscopy: a randomized, controlled trial. J Minim Invasive Gynecol 2005;12:210-5.

37. Narchi P, Benhamou D, Bouaziz H, Fernandez H, Mazoit JX. Serum concentrations of local anaesthetics following intraperitoneal administration during laparoscopy. Eur J Clin Pharmacol 1992;42:223-5.

38. Karadeniz Ü, Erdemli E, Ünver S, Yaşıtlı H, Ayoğlu H. Laparoskopik kolesistektomi sonrası postoperatif ağrı tedavisinde intraperitoneal bupivakain enjeksiyonu ve infüzyonu. Anestezi Dergisi 2003;11:226-30.

39. Inan A, Sen M, Dener C. Local anesthesia use for laparoscopic cholecystectomy. World J Surg 2004;28:741-4.

40. Raetzell M, Maier C, Schröder D, Wulf H. Intraperitoneal application of bupivacaine during laparoscopic cholecystectomy--risk or benefit? Anesth Analg 1995;81:967-72.

41. Radhofer-Welte S, Rabasseda X. Lornoxicam, a new potent NSAID with an improved tolerability profile. Drugs Today [Barc] 2000;36:55-76.

42. Balfour JA, Fitton A, Barradell LB. Lornoxicam. A review of its pharmacology and therapeutic potential in the management of painful and inflammatory conditions. Drugs 1996;51:639-57.

43. Staunstrup H, Ovesen J, Larsen UT, Elbaek K, Larsen U, Krøner K. Efficacy and tolerability of lornoxicam versus tramadol in postoperative pain. J Clin Pharmacol 1999;39:834-41.

44. Nørholt SE, Sindet-Pedersen S, Larsen U, Bang U, Ingerslev 
J, Nielsen $\mathrm{O}$, et al. Pain control after dental surgery: a double-blind, randomised trial of lornoxicam versus morphine. Pain 1996;67:335-43.

45. Rosenow DE, van Krieken F, Stolke D, Kursten FW. Intravenous administration of lornoxicam, a new NSAID, and pethidine for postoperative pain. A placebo-controlled pilot study. Clin Drug Invest 1996;11:11-9.

46. Ilias W, Jansen M. Pain control after hysterectomy: an observer-blind, randomised trial of lornoxicam versus tramadol. Br J Clin Pract 1996;50:197-202.

47. Trampitsch E, Pipam W, Moertl M, Sadjak A, Dorn C, Sittl $\mathrm{R}$, et al. Preemptive randomized, double-blind study with lornoxicam in gynecological surgery. [Article in German] Schmerz 2003;17:4-10. [Abstract]

48. Moller R, Covino BG. Cardiac electrophysiologic properties of bupivacaine and lidocaine compared with those of ropivacaine, a new amide local anesthetic. Anesthesiology 1990;72:322-9.

49. Feldman HS, Arthur GR, Covino BG. Comparative systemic toxicity of convulsant and supraconvulsant doses of intravenous ropivacaine, bupivacaine, and lidocaine in the conscious dog. Anesth Analg 1989;69:794-801.
50. Scott DB, Lee A, Fagan D, Bowler GM, Bloomfield P, Lundh R. Acute toxicity of ropivacaine compared with that of bupivacaine. Anesth Analg 1989;69:563-9.

51. Martinsson T, Oda T, Fernvik E, Roempke K, Dalsgaard CJ, Svensjö E. Ropivacaine inhibits leukocyte rolling, adhesion and CD11b/CD18 expression. J Pharmacol Exp Ther 1997;283:59-65.

52. Karamanlioglu B, Turan A, Memis D, Kaya G, Ozata S, Ture $M$. Infiltration with ropivacaine plus lornoxicam reduces postoperative pain and opioid consumption. Can J Anaesth 2005;52:1047-53.

53. Dobbs FF, Kumar V, Alexander JI, Hull MG. Pain after laparoscopy related to posture and ring versus clip sterilization. Br J Obstet Gynaecol 1987;94:262-6.

54. Helvacioglu A, Weis R. Operative laparoscopy and postoperative pain relief. Fertil Steril 1992;57:548-52.

55. Louizos AA, Hadzilia SJ, Leandros E, Kouroukli IK, Georgiou LG, Bramis JP. Postoperative pain relief after laparoscopic cholecystectomy: a placebo-controlled doubleblind randomized trial of preincisional infiltration and intraperitoneal instillation of levobupivacaine $0.25 \%$. Surg Endosc 2005;19:1503-6. 